\title{
SENCERizing a Biology General Education (Gen-Ed) Course ${ }^{1}$
}

\author{
Jorge A. Santiago-Blay ${ }^{2}$, Suzanne C. Shaffer ${ }^{3}$, and Barbara Eshbach ${ }^{4}$ \\ "It is about the real value of a real education, which has almost nothing to do with knowledge, and \\ everything to do with simple awareness; awareness of what is so real and essential, so hidden in \\ plain sight all around us, all the time, that we have to keep reminding ourselves over and over: "This \\ is water."” (Wallace 2005) http://web.ics.purdue.edu/ drkelly/DFWKenyonAddress2005.pdf, \\ https://www.youtube.com/watch?v=8CrOL-ydFMI \\ This paper is wholeheartedly dedicated to the thirteen undergraduates who enriched our lives during \\ the summer and fall of 2014 by demonstrating how far education can go when, \\ in spite of limitations, there are motivation and inspiration!

\begin{abstract}
We describe an effort to teach non-science majors' general education courses using the SENCER paradigm, namely, to "strengthen student learning and interest in the sciences, technology, engineering, and mathematics by connecting course topics to issues of critical local, national, and global importance."
\end{abstract}

Key Words: General Education courses, course redesign, STEM, sciences, technology, engineering, and mathematics, SENCER, life-long learning, complex problems, pragmatism, STEM education, higher education, civic engagement, cultural cognition, curriculum, education, communication, imagination, multidisciplinarity, high-impact educational practices

\section{Introduction: To Raise Awareness}

Several years ago, we listened to a recording of a 2005 commencement speech given by the late David Foster Wallace at Kenyon College (Gambier, Ohio, USA). The words, quoted above, spoken towards the end of the speech, summarize our motivation to redesign courses for college-level, non-science majors: to raise awareness about important societal issues and to build science literacy in non-science majors. We, and most of our readers, are familiar with the challenging facets of a college-level education. Some of those include student under-preparedness for college-level work and, more fundamentally, a general lack of engagement which we believe partly begins with a diminished sense of curiosity and motivation (hooks 1994, Deci 1996). However, in spite of those hurdles, we try to begin each term with renewed hope and vigor, to accomplish two goals: 1) to awaken students' interest in scientific issues that

\footnotetext{
${ }^{1}$ Submitted on March 19, 2015. Accepted on March 31, 2005. Final revisions received on April 15, 2015.

2 Department of Paleobiology, National Museum of Natural History, Washington, District of Columbia 20560 USA. E-mail: blayj@ si.edu

3 Instructional Designer, The Pennsylvania State University. 1031 Edgecomb Avenue, York, Pennsylvania, USA 17403. E-mail: scs15@psu.edu

${ }^{4}$ Head Librarian, The Pennsylvania State University. 1031 Edgecomb Avenue, York, Pennsylvania, USA 17403. E-mail: bee11@psu.edu
} 
impact their everyday lives and, ultimately, 2) to prepare an educated citizenry with the ability to think ethically and critically.

In this paper, we describe our efforts to achieve these goals through the redesign of general education (herein abbreviated gen-ed) courses in biology using the SENCER (Science Education for New Civic Engagements and Responsibilities) model. Herein, we: 1) characterize a SENCER course, 2) provide the local context for our course redesign, 3) explain the course redesign process, and 4) describe the next steps for and concerns about our voyage. Our ultimate goal is to more fully engage students in real-world scientific endeavors and awaken in them an interest in civic responsibility. We hope that this highimpact practice will be expanded to include other science gen-ed courses and more faculty members.

\section{What makes a course a SENCER Course?}

SENCER began in 2001 under the National Science Foundation's Course, Curriculum, and Laboratory Improvement (CCLI) funding track. SENCER's mission states: "SENCER courses and programs strengthen student learning and interest in the sciences, technology, engineering, and mathematics by connecting course topics to issues of critical local, national, and global importance" (SENCER.net).

\section{A SENCER Course Embodies the SENCER Ideals}

Over time, SENCER practitioners have developed a set of underlying principles that they use to guide their practice. Rather than re-write what has already been expertly and concisely articulated, we place them here in their entirety. SENCER approaches to education:

- Robustly connect science and civic engagement by teaching "through" complex, contested, capacious, current, and unresolved public issues "to" basic science.

- Invite students to put scientific knowledge and the scientific method to immediate use on matters of immediate interest to students.

- Help reveal the limits of science by identifying the elements of public issues where science does not offer a clear resolution.

- Show the power of science by identifying the dimensions of a public issue that can be better understood with certain mathematical and scientific ways of knowing.

- Conceive the intellectual project as practical and engaged from the start, as opposed to science education models that view the mind as a kind of "storage shed" where abstract knowledge may be secreted for vague potential uses.

- Seek to extract from the immediate issues the larger, common lessons about scientific processes and methods. 
- Locate the responsibilities (the burdens and the pleasures) of discovery as the work of the student.

- Focus on contested issues, [and thereby] encourage student engagement with "multidisciplinary trouble"5 and with civic questions that require attention now. By doing so, SENCER hopes to help students overcome both unfounded fears and unquestioning awe of science.

From these ideals it is clear that the goals of SENCER are to build students' awareness of complex problems in society while at the same time to give them tools (scientific method and other processes) to think critically about problems and posit solutions. In sum, students' awareness is increased through their engagement in solving complex civic issues that require problem solving.

\section{A SENCER Course has the Qualities Expressed in the SENCER Rubric}

Given the SENCER Ideals, how does one bring them to life within a course? The SENCER rubric is a good place to find concrete direction to start the design process. Typically, a course design includes the consideration of course objectives, activities, and assessments which encompass a given range of content. Course design rubrics are often thought of as a summative assessment tool - to be used to evaluate a project at its conclusion. However, this rubric could also be used in a "backwards design" approach at the beginning of a redesign project where one considers the outcomes of instruction first, and then plans backwards to develop activities that help students to reach those outcomes (Wiggins and McTighe 2005). In this approach, instructors could begin by asking, "What qualities should students develop and what should they be able to do at the end of a SENCER course?" The SENCER rubric helps instructors to answer this question first, followed by considerations of activities, assessments, and instructional approaches that help students to reach these outcomes. Redesign becomes very rich and rewarding as instructors consider content goals, SENCER Ideals, and learning outcomes in a holistic and iterative process that incorporates elements in the SENCER rubric.

The SENCER rubric has the following ten main sections:

- Student and faculty collaboration in choosing a course's main foci to include unsolved, complex, and important civic issues.

- Catalog of the civic issues to be addressed by the course "through which" the science content will be taught.

\footnotetext{
${ }^{5}$ Interdisciplinarity refers to two or more different disciplines coming together for a purpose, such as solving a problem. There are different approaches to interdisciplinary problem-solving. The multidisciplinary approach fosters the generation of tentative solutions by experts within different fields. Thereafter, those individual solutions are discussed by experts in different fields. The transdisciplinary approach, in contrast, favors the meeting of the experts in different fields first.
} 
- Content-based learning goals (think of this as the traditional content of the science course that is normally taught).

- Instructional strategies that create the place and space to address both the civic issues and STEM content (can include a focus on undergraduate research and preparing students for future civic engagement and responsibilities).

- Opportunities for putting new knowledge into action.

- Assessment of the course, student learning outcomes, and instructor for continual improvement.

- Promotion of interdisciplinary learning.

- Explicit incorporation of 21 st century skills.

- Sustainability of the course within the institution's curriculum.

- Sharing the results of the redesign with the wider STEM education community.

\section{How does one Prepare to Teach a SENCER Course?}

SENCER conducts a Summer Institute at which faculty members new to the process find out about the history of SENCER, meet the founders and practitioners of SENCER, and spend five fruitful days at workshops and presentations on many aspects of SENCER from design through assessment. A unique aspect of the Summer Institute is the chance to meet several times with a SENCER coach - a faculty member already using the SENCER model who is a source of support in the development of each new faculty member's project. Networking opportunities and the regional support system are also quite strong. Meetings with regional SENCER groups and leaders help participants stay connected after the Institute. Additional professional activities are held through the year at different SENCER regions in the USA and sometimes abroad.

\section{Why is SENCER important? Building an Educated Citizenry}

We consider it relevant to discuss the importance of a SENCER approach in the current political, social, and educational climate in the U.S. The setting for our project is the York Campus of The Pennsylvania State University, herein referred to as Penn State York, located in York, Pennsylvania. In the context of U.S. history, York is important because it was as one of the first capitals of what was to become the United States of America. More recently (2005), and in the context of the so-called evolution-creation debate, the limelight shone on York County in a case in which the nature of science education was debated (Kitzmiller v. Dover Area School Dist 2005, Padian 2009).

This legal case that took place locally, and had huge national repercussions serves as an excellent example for the need to educate college students (especially non-science majors) in the practice of sound scientific thinking as it applies to the "complex, contested, capacious, current, and unresolved public issues" that exist locally and globally. SENCER encourages the development of scientific thinking at the same time as it encourages active and informed civic 
engagement. This need is also highlighted in a recent issue of Science, including the statement, "Biology teachers lack the skills and... to teach it properly" (Mervis 2015), illustrating the role that SENCER could play in providing instructors with the tools they would need to feel confident in tackling such challenging and timely controversies in science education.

\section{SENCER Comes to Penn State York}

Penn State York is one of more than twenty Penn State campuses statewide and is a relatively small, student-centered campus that includes approximately 1100 non-residential students; about $25 \%$ of them are adult learners. The coursework for the first two years of more than 160 Penn State baccalaureate majors is offered, as well as eight baccalaureate degrees, five associate degrees, and one master's degree. Penn State York is located in south-central Pennsylvania, approximately a two-hour drive from Washington, District of Columbia, the capital of the USA, and Philadelphia, Pennsylvania, the city with the largest population in the state. The campus rests on 51 acres that overlook the historic City of York. The undergraduate degrees at Penn State include 35$38 \%$ gen-ed credits. Currently, the gen-ed curriculum follows a traditional model consisting of a menu of courses across the arts, humanities, social

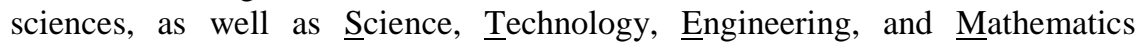
(STEM). These STEM gen-ed courses include astronomy, chemistry, information sciences and technology, meteorology, as well as biology, to name a few. There are four gen-ed courses in the biological sciences at Penn State York: Structure and Function of Organisms; Genetics, Ecology, and Evolution, Environmental Science, and Human Body: Form and Function. Gen-ed courses often serve dual purposes at Penn State: as electives for students from other disciplines, or as gateway-to-major courses for those within the major. Inasmuch as the STEM courses are often critically important in the modern world, it is disheartening to know that often non-science majors are hesitant to take gen-ed STEM courses because they are anxious about or disinterested in the topics discussed in the courses This happens to the detriment of the overall education of non-science majors and can affect their ability to contribute responsibly to society as well-informed citizens. It is our hope that through this redesign process, we can make courses more interesting and relevant to a wider undergraduate population on campus.

\section{The Redesign}

Most of the gen-ed science courses at Penn State York are taught by adjunct instructors (author JASB included) and are taught in a traditional lecture-based approach. There are several concerns with our desire to change this model. While we understand the benefits of active learning on students' motivation and engagement with course material, we are also keenly aware of the welldocumented resistance that students can give when asked to assume more 
responsibility for their own learning in active models (Weimer 2002). We consider that part of any redesign plan must include early conversations about the design and expectations in the course so that students can make changes if they are uncomfortable or unwilling to complete the course as designed. Another strategy we plan to employ is to build the model slowly over time, incorporating only one or two modules in the first iteration of the redesign so as to address challenges and problems on a smaller scale initially.

\section{Choosing a Course and Identifying Issues}

We chose the campus environmental science gen-ed course as the target course for redesign because of the natural fit between the content and civic issues that could be addressed. Every topic has obvious connections to problems and challenges faced locally and globally. We started by doing an inventory of the topics to be covered, followed by brainstorming the many possible relevant questions/issues that could be associated with each (Table 1).

\section{Table 1 Sampling of Typical Environmental Science Units and Associated} Issues

\begin{tabular}{|c|c|}
\hline Main Topic & Relevant Issues/Questions/Problems \\
\hline $\begin{array}{l}\text { Understanding our } \\
\text { Environment }\end{array}$ & $\begin{array}{l}\text { - What are the big environmental questions/problems of our } \\
\text { time? } \\
\text { - How should we proceed with the class? What should guide } \\
\text { us? What processes and approaches can we use to make } \\
\text { sure we are thinking scientifically and ethically? } \\
\text { - What projects interest you and how would you proceed? }\end{array}$ \\
\hline $\begin{array}{l}\text { Environmental } \\
\text { Systems }\end{array}$ & $\begin{array}{l}\text { - How are we connected to the environment? } \\
\text { - How do environmental changes in one area impact another? }\end{array}$ \\
\hline Evolution & $\begin{array}{l}\text { - What happens when our world has decreasing biodiversity? } \\
\text { - How can we think scientifically about evolution (even if we } \\
\text { don't believe)? }\end{array}$ \\
\hline $\begin{array}{l}\text { Human } \\
\text { Populations }\end{array}$ & $\begin{array}{l}\text { - Is overpopulation a real phenomenon? } \\
\text { - Why does human population size matter? } \\
\text { - Should it be controlled? If so, how and by whom? } \\
\text { - What is the history of human migration? What are the } \\
\text { drivers of migration and population growth/change? }\end{array}$ \\
\hline $\begin{array}{l}\text { The Problem of our } \\
\text { own Waste }\end{array}$ & $\begin{array}{l}\text { - Where does our garbage go in York County? What can be } \\
\text { improved in the current system? How would you go about } \\
\text { it? } \\
\text { - What are the biggest national and global refuse issues and } \\
\text { proposed solutions? } \\
\text { - How would your group tackle these issues? }\end{array}$ \\
\hline Enough to Drink? & $\begin{array}{l}\text { - What is the water system in York County? Where do we get } \\
\text { our water and where does our waste water go? } \\
\text { - Who regulates and monitors the quality of our water? }\end{array}$ \\
\hline
\end{tabular}




\begin{tabular}{|l|l|}
\hline & $\begin{array}{l}\text { - How does our water system connect with other regional } \\
\text { systems and what are the issues? } \\
\text { - Nationally and internationally, what are the major water } \\
\text { issues and how does our local water use connect to these } \\
\text { larger issues? }\end{array}$ \\
\hline $\begin{array}{l}\text { Food and } \\
\text { Agriculture }\end{array}$ & $\begin{array}{l}\text { - What are the local, national, and global hunger hotspots? } \\
\text { - Why? }\end{array}$ \\
& $\begin{array}{l}\text { - Who goes hungry and why? } \\
\text { effective? }\end{array}$ \\
\hline Climate Change & $\begin{array}{l}\text { - What changes would you make to improve things? } \\
\text { - Global climate change: Fact or fiction? } \\
\text { - What are the impacts of climate change? } \\
\text { - What is the current scientific research? } \\
\text { - What is being done to address it? } \\
\text { - What still needs to be done? }\end{array}$ \\
\hline
\end{tabular}

\section{Developing a Module}

Next, we started to think about possible modules for a few of the identified issues which would include the scientific content to be covered, an associated civic issue/problem to be solved, activities to be completed to solve the issue and learn the content, avenues for sharing the results, and assessment. Going back and forth between our ideas and the rubric elements as well as the SENCER Ideals, helped us to stay on track. For example, we needed to concretely think about including $21^{\text {st }}$ century skills and interdisciplinary components in the design, which we had not thought about originally. This iterative process helped not only to refine our design, but also to solidify for us, a deeper understanding of the SENCER Ideals. Table 2 provides an example of a sample module including these elements.

Table 2. Sample Module with Incorporation of Rubric Elements.

\begin{tabular}{|c|c|}
\hline \multicolumn{2}{|r|}{ Topic: Our Food Supply } \\
\hline $\begin{array}{l}\text { SENCER Rubric } \\
\text { Elements }\end{array}$ & Course Module Element \\
\hline $\begin{array}{l}\text { Learning Goals: } \\
\text { 1.Content }\end{array}$ & $\begin{array}{l}\text { By the end of the unit, students will be able to: } \\
\text { 1. Content Goals } \\
\text { - Describe the many aspects of global hunger and the } \\
\text { associated health risks } \\
\text { - Describe the major food crops around the world } \\
\text { - Describe the environmental costs associated with } \\
\text { farming } \\
\text { 2. } 21^{\text {st }} \text { Century Skills } \\
\text { - Demonstrate ethical decision making practices } \\
\text { incorporated in the problem-solving process }\end{array}$ \\
\hline
\end{tabular}




\begin{tabular}{|c|c|}
\hline & $\begin{array}{l}\text { - Demonstrate evidence of sound critical and scientific } \\
\text { thinking }\end{array}$ \\
\hline $\begin{array}{l}\text { Associated Civic } \\
\text { Questions, Problems, } \\
\text { or Issues }\end{array}$ & $\begin{array}{l}\text { - What are the local, national, and global hunger hotspots? } \\
\text { Why? Or, who goes hungry and why? } \\
\text { - Who addresses hunger locally, nationally, globally? Is it } \\
\text { effective? } \\
\text { - What changes would you make to improve things? } \\
\text { of the Chesapeake Bay? }\end{array}$ \\
\hline $\begin{array}{l}\text { Activities: By Group } \\
\text { Doing the Project }\end{array}$ & $\begin{array}{l}\text { - After meeting with the instructor, students will choose to } \\
\text { investigate some of the associated questions (or ones of } \\
\text { their own choosing) as described above. } \\
\text { - During the Food Supply Unit, the group will present their } \\
\text { problem and proposed solutions for improvement/ change. } \\
\text { - Each presentation also needs to contain a discussion of the } \\
\text { scientific and ethical considerations that should be taken } \\
\text { into account when proposing solutions (Paul and Elder } \\
\text { 2008; Markkula Center, Santa Clara University 2014). } \\
\text { - Students write a summary article to be posted in the class } \\
\text { newsletter on their topic. }\end{array}$ \\
\hline $\begin{array}{l}\text { Activities: By Students } \\
\text { in the Audience }\end{array}$ & $\begin{array}{l}\text { During student presentations, students in the audience bring } \\
\text { examples or questions related to the topic to add to the } \\
\text { discussion and are encouraged to challenge the group in } \\
\text { terms of the quality of their scientific and ethical approaches } \\
\text { to the analysis. They hand in their contributions on an index } \\
\text { card at the end of class. }\end{array}$ \\
\hline $\begin{array}{l}\text { Transforming New } \\
\text { Knowledge to Action }\end{array}$ & $\begin{array}{l}\text { The class discussion ends with a brainstorming session } \\
\text { called, "What more can we do about this issue?" } \\
\text { Bonus points can be earned by groups who take up the } \\
\text { challenge to action. }\end{array}$ \\
\hline $\begin{array}{l}\text { Assessment: } \\
\text { 1. Project }\end{array}$ & 1. Project Assessment: Rubric to assess project components \\
\hline 2. Audience & $\begin{array}{l}\text { 2. Audience Assessment: Student earn points for each } \\
\text { substantive addition to the discussion }\end{array}$ \\
\hline 3. Whole Class & $\begin{array}{l}\text { 3. Whole Class: Weekly online quiz, exams, project, outside } \\
\text { events }\end{array}$ \\
\hline 4. Course & $\begin{array}{l}\text { 4. Course Assessment: SENCER-SALG, Student evaluations, } \\
\text { end-of-course satisfaction survey, pre-/post-test of course } \\
\text { content. }\end{array}$ \\
\hline $\begin{array}{l}\text { Interdisciplinary } \\
\text { Element }\end{array}$ & $\begin{array}{l}\text { - Nutrition instructor invited to do a guest lecture on the } \\
\text { impact of hunger on human health and wellness. } \\
\text { - Library-sponsored events that incorporate speakers from } \\
\text { multiple disciplines discussing the topics. }\end{array}$ \\
\hline Sharing & $\begin{array}{l}\text { Results of group projects are shared online via class } \\
\text { newsletter. }\end{array}$ \\
\hline
\end{tabular}


A typical module would begin with an introductory lecture/overview by the instructor. Guest speakers would also be integrated to ensure that multidisciplinary aspects were incorporated. For example, the nutrition instructor could be invited to speak during the unit on food supply to talk to students about the impacts of hunger on human wellness. Local farmers who minimize the impact of agricultural runoff into the Susquehanna/Chesapeake could also be invited to talk about the environmental concerns of farm waste in the local watershed. This introduction to each topic would be followed by a presentation by one student group working on the associated problem. They would be charged with exploring the issue at a local, national, and global level. They would describe the issue and then their proposed solutions. They would need to also point out the elements of scientific and ethical thinking that they used to analyze and address the problem. A final report, written by the group, would be summarized and posted to an online class newsletter which would then include all groups' summaries by the end of the semester. Students watching the presentations would be charged with bringing examples or questions related to the topic to add to the discussion and would be encouraged to challenge the group in terms of the quality of their scientific and ethical approaches to the analysis. Students in the audience would earn points for the contributions to the discussion. All students would complete a weekly online quiz on the general topic. Exams would take place five times during the semester and would cover lectures, group presentations, and other relevant material.

\section{Integrating Content Objectives with $21^{\text {st }}$ Century Skills}

When we began to think about the course as a series of problems to be solved rather than simply content to be learned, we decided to give students problem-solving strategies and critical thinking approaches that could also address $21^{\text {st }}$ century skill development as prescribed by the SENCER rubric. We decided on two different support tools, Paul and Elder's Scientific Thinking from their Critical Thinking Series (2008) and The Markkula Center for Applied Ethics at Santa Clara University's ethical decision-making tool (Santa Clara University 2014). As students attempt to solve the environmental problems, they must integrate both solid scientific thinking and ethical principles using these tools. The American Association for Colleges and Universities (AAC\&U) also provides a free tool called VALUE Rubrics which can shed light on the components of ethical and critical thinking as well as civic engagement, and could be very useful to faculty in further assessing student learning and growth.

\section{Incorporating Interdisciplinary Components and the Library}

One of the important aspects of SENCER is to help students understand the complexity inherent in solving contemporary issues. Very few problems (and their solutions) are straightforward. They often require knowledge of subjects that extend beyond the content being studied. Interdisciplinary approaches, then, 
make sense in terms of broadening student perspectives. To build this aspect into the course, we decided early on that it is vital to partner with our campus librarians to develop meaningful co-curricular programming that could encourage students to think beyond the course content. The timing for this collaboration was perfect, as our campus library is currently piloting a first-year experience (FYE) program in hopes of increasing student engagement in our our commuter campus community, improving first-year student success, and creating an awareness of the value of academic libraries (Oakleaf 2010). While programming is an integral part of what public libraries contribute to their communities, programming in an academic library usually takes the form of course-related library instruction sessions and a few research workshops. This FYE model expands the library's role beyond course-based academic support by providing additional programming that gives students opportunities to engage socially and intellectually with faculty, staff, and other students through topics of interest. The events are designed to be interdisciplinary, encouraging attendees to engage in conversations from multiple perspectives on a variety of topics. One of the aspects of the library FYE is civic and social literacy, which fits into the SENCER approach of a "focus on contested issues... with civic questions that require attention now".

Academic libraries, by their very nature, are highly interdisciplinary, so we saw this FYE program as an excellent venue to collaborate on programming to support the attainment of the SENCER Ideals. We envision working with the librarians to create monthly events open to the campus and community to be held in the library. These events would highlight relevant course topics and incorporate multi-disciplinary perspectives. Another idea would be to create a common conversation in the community in much the same way that a community-wide reading program (such as the "One Book" program) is designed to do. This collaborative research approach, known as communitybased participatory research (CBPR) is already being utilized in the area of public health, often with the support of the National Institutes of Health (NIH). This approach could encourage a wider sharing of student projects and solutions with the community-at-large. We strongly believe that partnering with the library to facilitate interdisciplinary programming and student engagement beyond the classroom would become an integral part of the course redesign.

\section{Encouraging Student Input}

An important part of the redesign calls for student input into the design process. The plan in the first iteration is to develop several module "projects" so that students can choose topics of individual interest, to be completed as a project portion of the grade. Student teams would present their work during that portion of the course with the associated content. To help students prepare for their presentation, 15 minutes each week would be given for groups to connect and plan for their tasks. The instructor would meet with each group twice: 
initially to get their plans formulated and again the week before presentation to make sure the projects were rigorous enough and on track.

Conversations about SENCER Ideals and goals would be central to the course delivery so that students understand the underlying reason for the course design and the process in which they will participate. The challenge will be to design activities that are truly possible to complete by students independently and which are rigorous, as well as interesting.

\section{Undergraduate Research and Honors Option (Figures 1-3)}

Coincidentally, at the same time that we attended the SENCER Summer Institute, JASB and undergraduates had already begun research on a local, small creek, called Poor House Run (PHR, an abbreviation used on some manhole covers in the City of York, Pennsylvania). By the time we had finished the summer SENCER workshop, it had become obvious that PHR could be a powerful vehicle to carefully tackle important issues in environmental sciences, such as the importance of environmental sciences, water chemistry and pollution, biodiversity, waste, conservation, restoration, human health, etc.

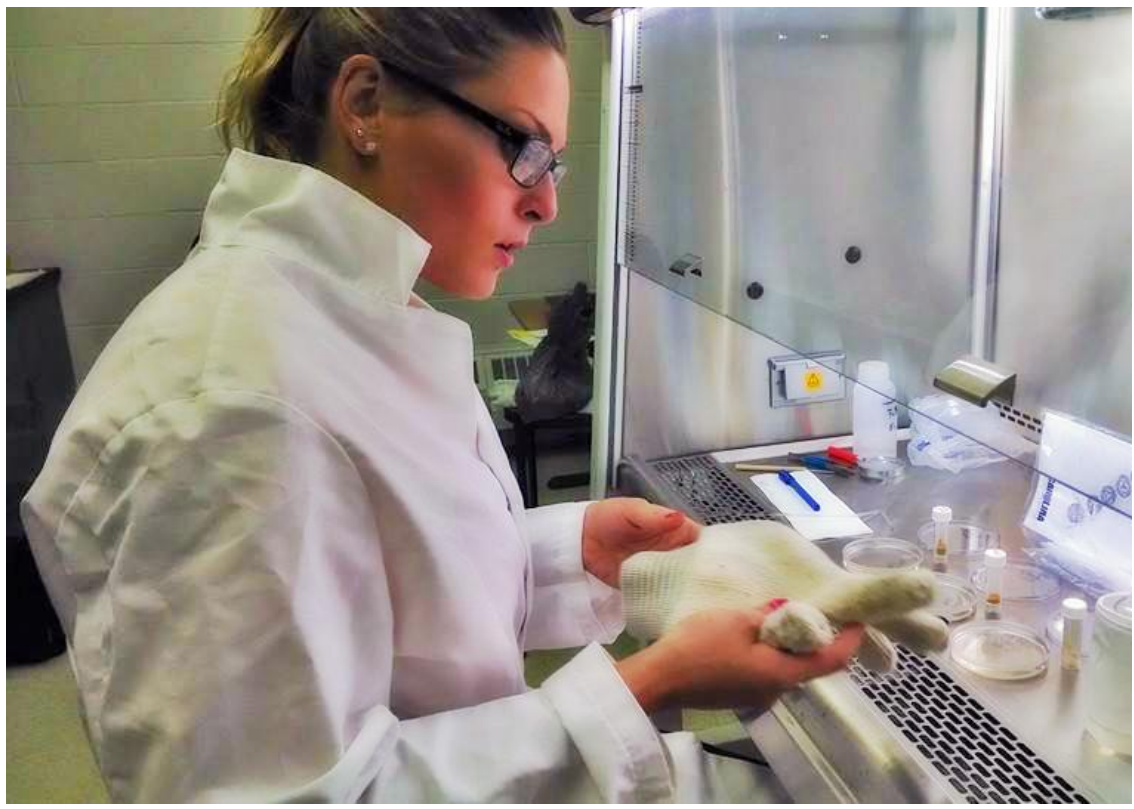

Figure 1. Nichole Wrobel getting ready to work on a Ceratopteris fern (C-fern) research project during the summer 2014. All students on Figures 1-3 kindly gave permission to use their images. All images on Figures 1-3 lightly touched by E. Leavell (The ITSupport Center). 

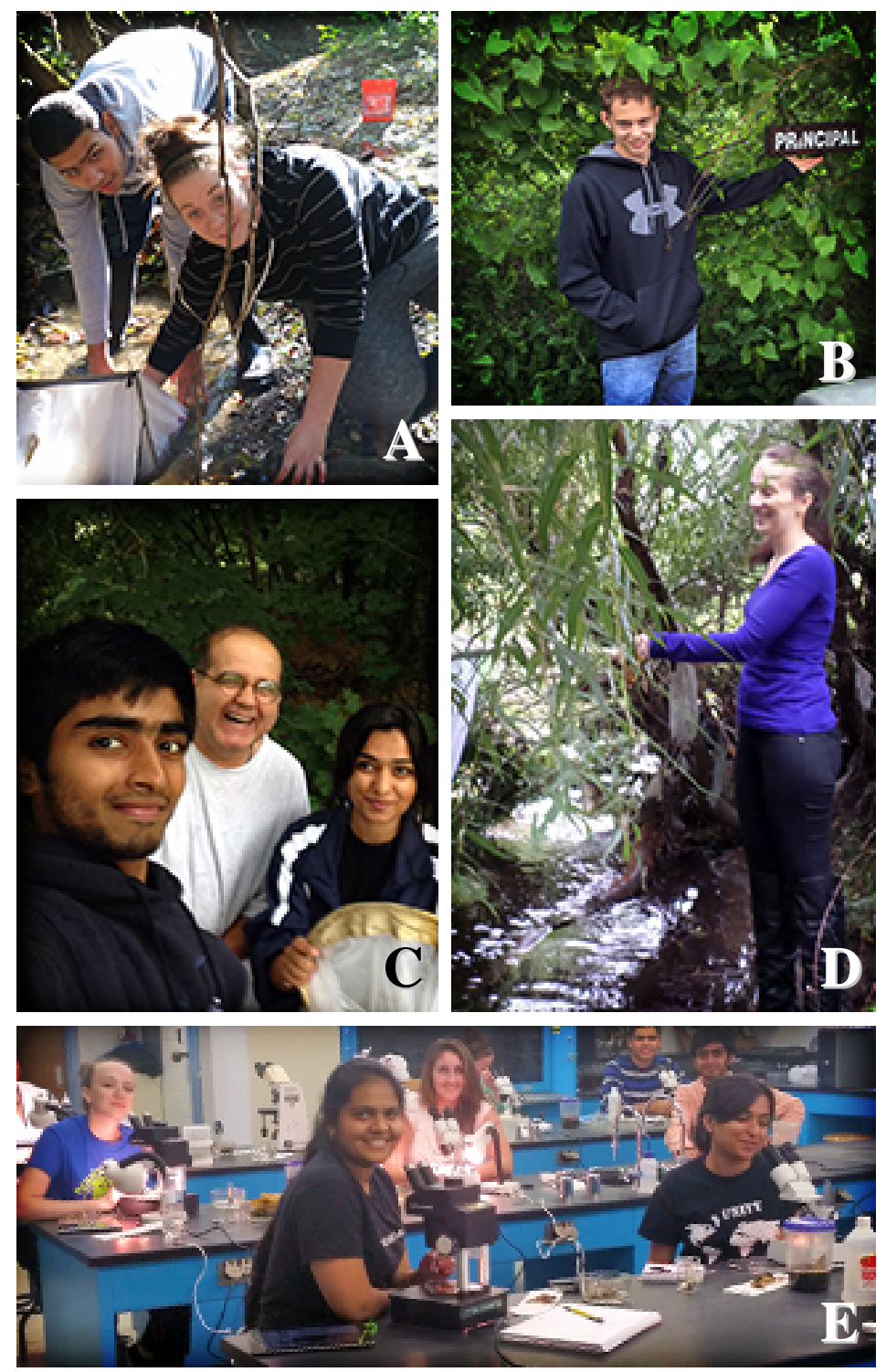

Figure 2. Undergraduate research students hard at work collecting, sorting, and learning with joy during the fall 2014 semester at Penn State York. A. Daved Fouad and Abigail Doniecki sampling with the Surber sampler. B. Brandon Merkert. C. Rajeev Joshi (left) and Aruba Tariq (right). D. Merna Mikail collecting aerial insects. E. Sorting insects. Distal bench (left to right), A. Donieki, D. Fouad; middle bench, M. Mekail, Taylor Mandara, and R. Joshi; proximal bench, Goral Patel and A. Tariq. The organisms sorted by these and other dedicated students are being prepared by author JASB for further scientific study. Photo on panel "E" taken by S. Brown, reproduced with permission. 

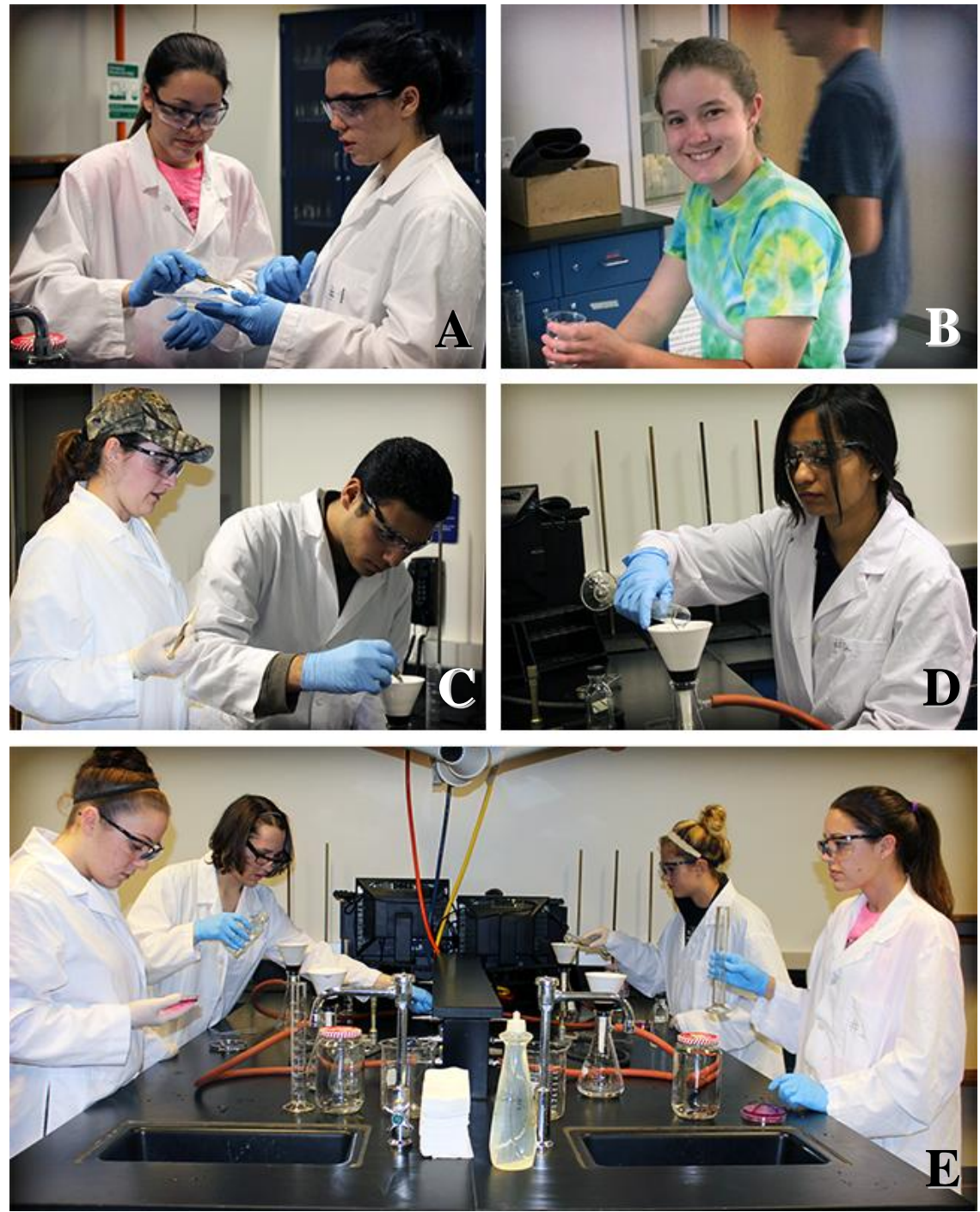

Figure 3. Undergraduate students performing microbiological analyses of the water in Poor House Run, York, Pennsylvania as part of Microbiology Laboratory (Microbiology 202) course during the fall 2014 semester. In addition to a plethora of "canned" exercises, every opportunity was used conduct original research. A. Abigail Snyder (left) and Laura Ohl (right). B. Chelsey Bryant. C. Taylor Mandara (left) and Daved Fouad (right). D. Aruba Tariq. E. Abigail Doniecki, Kaleigh Lukacs, Erica Little, and A. Snyder. All images, except B, taken by B. Dennis. All images reproduced with permission from the students and Ms. Dennis. 
We have received excellent feedback from students involved in that project on how appropriate the activities would be for implementation in a revised gened course as an honors option or for undergraduate research. One of the challenges of incorporating a problem-based approach in a gen-ed course is the large enrollment in these courses and lack of teaching support for "laboratories" of non-science major courses. Faculty members at Penn State York do not have graduate assistants or staff to support large numbers of students in field situations, but a small honors cohort within the class might be possible.

\section{Assessment}

Assessment of student learning outcomes as well as overall course design will be completed on several levels. Students will be assessed (graded) for their performance on:

- the group project

- exams

- online quizzes

- participation during class

- participation in outside events (library or community)

Student learning outcomes and course satisfaction will be further assessed (non-graded) using the following:

- a course content pre-/post test

- the SENCER-SALG pre-/post-test

- student course evaluations

- post-course satisfaction survey

- VALUE Rubric

The SENCER-SALG is another SENCER-derived tool that is freely available for use online. It "allows students to rate how well specific activities in courses have helped their learning and also asks students to report on their science skills and interests, as well as the civic activities in which they engage". Table 3 shows the broad categories of questions asked in both the pre- and postsemester assessments. 
Table 3 Broad Question Categories on SENCER-SALG.

\begin{tabular}{|c|c|}
\hline $\begin{array}{l}\text { SENCER SALG Pre-semester } \\
\text { Assessment }\end{array}$ & $\begin{array}{l}\text { SENCER SALG Post-semester } \\
\text { Assessment }\end{array}$ \\
\hline - Confidence in science literacy skills & $\begin{array}{l}\text { - What gains have you made in } \\
\text { understanding the course content }\end{array}$ \\
\hline $\begin{array}{l}\text { - Confidence in general science course } \\
\text { skills }\end{array}$ & $\begin{array}{l}\text { - Do you see an increase in other } \\
\text { academic skills like textbook reading, } \\
\text { for example? }\end{array}$ \\
\hline - Interest in science literacy & $\begin{array}{l}\text { - How did the class impact your attitudes } \\
\text { about science and the content? }\end{array}$ \\
\hline -Interest in "advanced" science activities & $\begin{array}{l}\text { - To what extent were you able to } \\
\text { integrate your learning into everyday } \\
\text { life and other courses? }\end{array}$ \\
\hline - Levels of student civic engagement & $\begin{array}{l}\text { To what extent did the following help } \\
\text { your learning: } \\
\text { - Overall approach to the course } \\
\text { - In-class activities } \\
\text { - Graded Assignments } \\
\text { - Class resources (textbooks, } \\
\text { worksheets, etc.) } \\
\text { - General information provided about } \\
\text { the course } \\
\text { - Extra learning support opportunities }\end{array}$ \\
\hline $\begin{array}{l}\text { - What type of scientific preparation do you } \\
\text { already have, i.e. number of AP courses } \\
\text { taken? }\end{array}$ & $\begin{array}{l}\text { - How much time did you devote to your } \\
\text { studies for this course? }\end{array}$ \\
\hline
\end{tabular}

Each SENCER-SALG assessment has required elements to maintain the reliability and validity of the instruments as determined through research by Weston et al (2006). Additional questions can be added by instructors to suit their needs. According to Weston et al. (2006), the strongest aspect of the validity of the SENCER-SALG had to do with its utility in making course redesign decisions. It is in this light that we intended its use.

\section{Data Collection}

An Institutional Review Board (IRB) proposal was submitted by author SCS (IRB \# 863) and approved during the summer 2014, to begin collecting data to assess the effectiveness of the SENCER redesign. In the fall 2014 semester, during a traditional lecture format offering of the environmental science course, students took a course content pre-/post-test, completed student course evaluations, and completed pre-/post-semester SENCER-SALG assessments. We plan to use this benchmark data to make comparisons between students in the traditional course model (fall 2014) and those taking the redesigned SENCER course in the future. The data is interesting as it gives some 
indications of where a course redesign could have a positive impact on learning outcomes.

\section{Results and Discussion}

Pre-semester SENCER-SALG data $(\mathrm{n}=37)$ in Figure 4 show students' selfperceptions of their aptitude, interest, and attitudes towards science as well as the level of integration of scientific thought into their everyday lives. Clearly, there is plenty of room for improvement in all areas, including general understanding of scientific topics, skills in scientific approaches to thinking and learning, current attitudes towards learning science, and integrating science into everyday life.

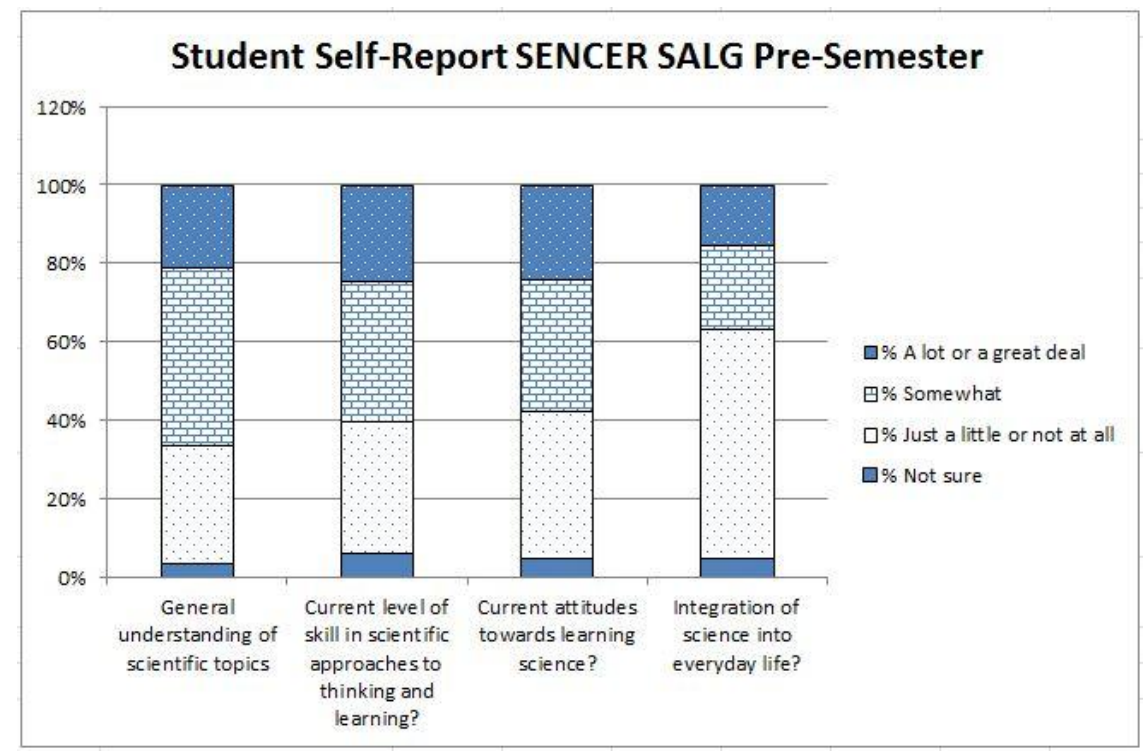

Figure 4. Student self-reported levels of scientific aptitude, interest, and attitudes using SENCER-SALG (Traditional Course, Pre-semester). N/A means not applicable.

Post-semester data from students $(\mathrm{n}=28)$ in a traditional lecture course who took SENCER-SALG provide a benchmark against which to measure future improvement with a new design using the SENCER model. Figures 5 and 6 show response averages by question category post-semester.

SENCER-SALG data pre- and post-semester confirmed our hypotheses that there are some gaps in student learning outcomes that occur when a traditional mostly-lecture model is used. For example, changing attitudes towards science and integration of scientific thinking into everyday life are two important areas that could be improved upon (Figure 5). Using the SENCER model to redesign a gen-ed science course, we hypothesize, could provide opportunities to make 
gains in those areas of scientific and civic literacy among non-science majors that currently do not seem to be addressed by traditional models of teaching and learning.

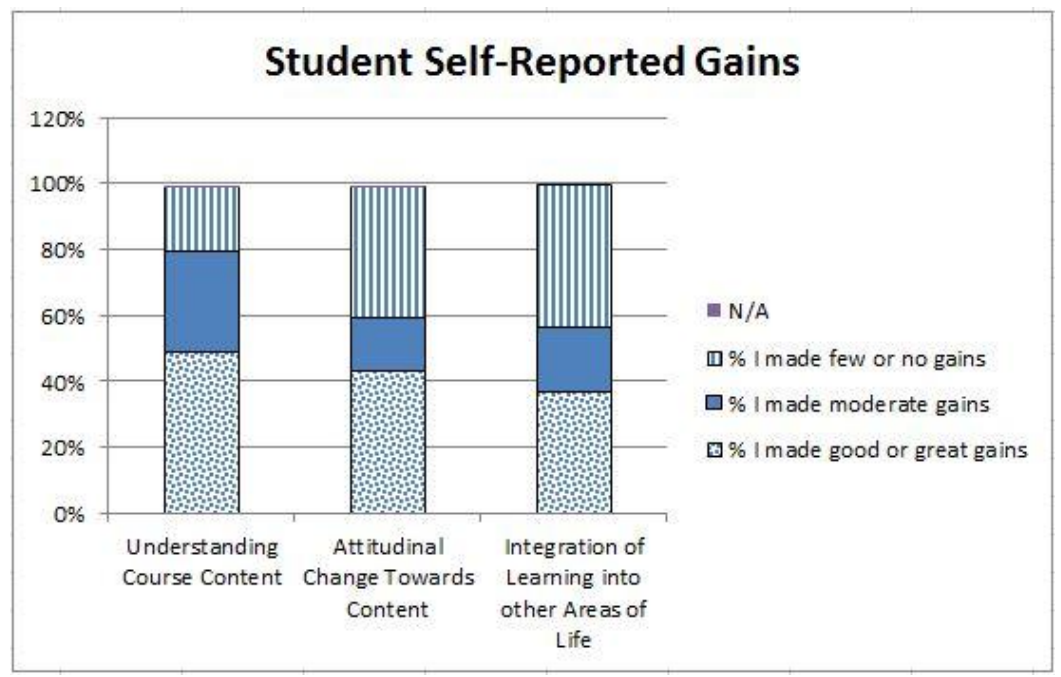

Figure 5. Student self-reported gains using SENCER-SALG (Traditional Course, Postsemester). N/A means not applicable.

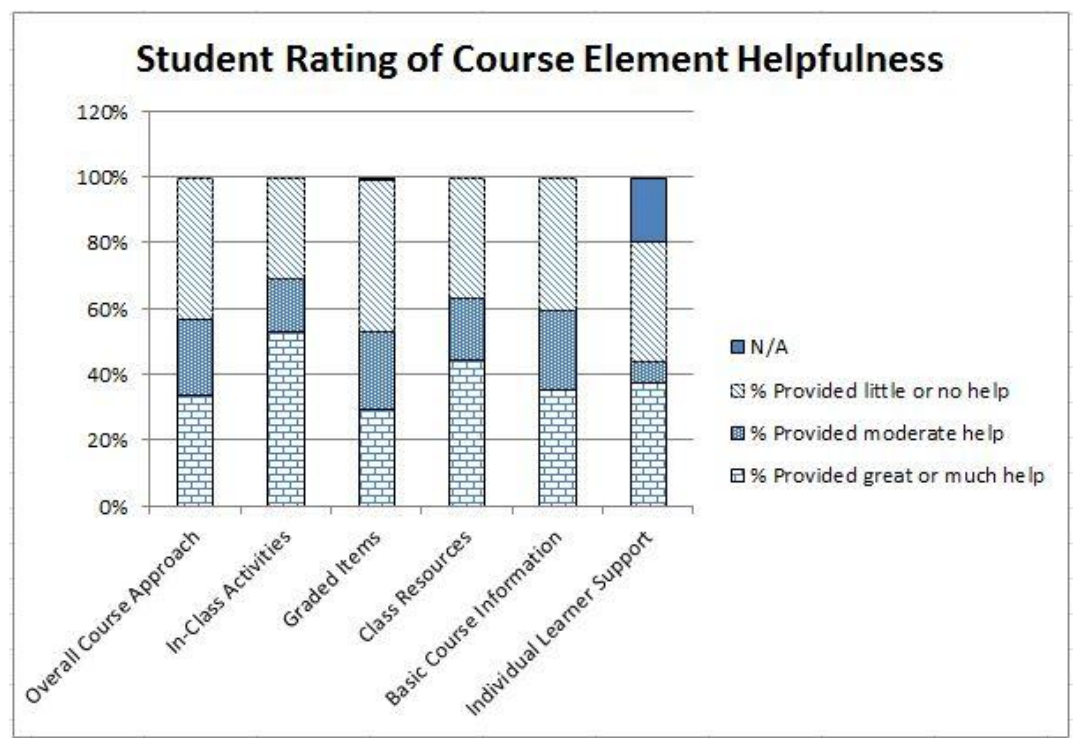

Figure 6. Student Rating of Course Element Helpfulness Using SENCER-SALG (Traditional Course, Post-semester). N/A means not applicable. 


\section{Next Steps and Concerns}

Our plan is to incorporate the SENCER redesign slowly, by giving students the option to complete a module, as described herein, in lieu of one course exam. We plan to use this as a pilot to give us the opportunity to address challenges in the design, in the hopes of moving to a wider integration in future semesters.

The authors are mindful of the pitfalls of trying to do too much in any course that has limited resources, including time, the challenges of developing inter-departmental cooperation, and administration buy-in and support. Perhaps, selecting three possible issues (described below) that the students could investigate that are tied to the area around York, Pennsylvania would be a good place to begin.

- The impact of farming and agriculture in York on the Susquehanna River and the Chesapeake Bay basins. Pollution that comes downstream from Pennsylvania, New York, and Maryland harms the Chesapeake Bay, causing great damage to marine life and fishing-based livelihoods.

- The impact of dams on the Susquehanna River and on Chesapeake Bay.

- The impact of nuclear reactors on the environment (c.f. Three Mile Island, located in the Susquehanna River, south of Harrisburg, capital of Pennsylvania).

The faculty members(s) teaching the course and librarian(s) could begin early to provide research materials on these issues (or other issues) earlier in the term. Students could focus early in the course and not invest time trying to find topics and supporting material. The professor and/or students could do short presentations on the pros/cons of each of the topics and then the students could choose which one(s) they would like to do. This allows greater control over the effort made by all parties and reduces the likelihood that the students would become discouraged by not finding research material expeditiously. This could be important for the less academically-experienced or able students.

Also, depending on the current and future teaching interests, will there be faculty members available to teach this using this approach after the current faculty move on? Sustainability of efforts within the curriculum and institution is in the SENCER rubric as an important criterion for evaluation.

In spite of our concerns, we see a need to increase students's interest in the sciences as well as their ability to think critically, scientifically, and ethically. We consider that the SENCER model of redesigning gen-ed science courses, offer us the opportunity to do this - thereby helping students to become more knowledgeable, engaged, and, above all, aware citizens. 


\section{Acknowledgements}

Two anonymous reviewers offered extremely valuable and constructive suggestions for which we are profoundly grateful. Our SENCER coach, Dr. Garon Smith (Department of Chemistry and Biochemistry, University of Montana, Missoula, Montana, USA) provided us with a plethora of resources, sound advice, and inspiration. Heather Drought read the next to last version of the paper and offered numerous corrections. Tracy Barbaro (Harvard University, Cambridge, Massachusetts, USA), Georgina Cullman (Center for Biodiversity and Conservation, American Museum of Natural History, New York, NY, USA), John Bull (Weber State University, Ogden, Utah, USA), William J. Kleindl (Flathead Biological Research Station, University of Montana and Naiad Aquatic Consultants, LLC, Bozeman, Montana, USA), Bruce Alan Noll (College of Education, University of New Mexico, Albuquerque, New Mexico, USA), Raquel Pereira (Barcelos, Portugal), Marc Srour (Enalia Physis Environmental Research Center, Cyprus), Jessica B. Turner (West Virginia University, Morgantown, West Virginia, USA), and Paul Weihe (Central College, Pella, Iowa, USA), made us aware of many valuable teaching resources that supplemented the ones we were aware of, and are listed in the Appendix.

\section{Literature Cited}

Deci, E. L. and R. Flaste. 1996. Why We Do What We Do: Understanding Self-Motivation. Penguin Books. New, York, NY, USA. 230 pp.

hooks, b. 1994. Teaching to Transgress: Education as the Practice of Freedom. Routledge. New York, NY, USA. 216 pp. Author hooks, prefers to use lowercase for her pen name; her given name is Gloria Jean Watkins, http://en.wikipedia.org/wiki/Bell hooks

Kitzmiller v. Dover Area School Dist. (Tammy Kitzmille, et al. Plaintiffs v. Dover Area School District et al., Defendants). No. 04cv2688.2005. United States District Court, M.D. Pennsylvania. Dec. 20, 2005. 400 F.Supp.2d 707 (M.D.Pa. 2005) https://www.bu.edu/lawlibrary/PDFs/research/portals/probonofiles/kitzmiller.pdf

Markkula Center for Applied Ethics. Santa Clara University. http://www.scu.edu/ethics/practicing/decision/

Mervis, J. 2015. Why many U.S. biology teachers are 'wishy-washy'. Science (American Association for the Advancement of Science, Washington, District of Columbia, USA). 347(6226): 1054 .

Oakleaf, M. 2010. Value of Academic Libraries: A Comprehensive Research Review and Report. Association of College and Research Libraries. Chicago. Published online at www.acrl.ala.org/value

Padian, K. 2009. The evolution of creationists in the United States: Where are they now, and where are they going? Comptes Rendus (Paris) Biologie 332:100-109. http://dx.doi.org/10.1016/j.crvi.2008.07.004

Paul, R. and L. Elder. 2008. The Miniature Guide for Students and Faculty to Scientific Thinking. The Foundation for Critical Thinking. http://www.criticalthinking.org/store/products/scientificthinking-for-students-and-faculty/170

Wallace, D, F. 2005. Transcription of the 2005 Kenyon Commencement Address - May 21, 2005. Written and Delivered by David Foster Wallace. http://web.ics.purdue.edu/ drkelly/DFWKenyonAddress2005.pdf. An audio version with some transcription in English is available in https://www.youtube.com/watch? $\mathrm{v}=8 \mathrm{CrOL}-\mathrm{ydFMI}$

Weimer, M. 2002. Learner-Centered Teaching: Five Key Changes to Practice. Jossey-Bass. San Francisco, California, USA. 258 pp.

Weston, T., E. Seymour, and H. Thiry. 2006. Evaluation of Science Education for New Civic Engagements and Responsibilities (SENCER) Project. Prepared for The National Center for Science and Civic Engagement. December 1, 2006. http://www.sencer.net/assessment/pdfs/final report_sencer 12 21 06. .pdf

Wiggins, G. and J. McTighe. 2005. Understanding by Design. Expanded second edition. Association for Supervision and Curriculum Development (ASCD). Alexandria, Virginia, USA. 370 pp. 


\section{Appendix}

\section{Some internet-based resources in biology, subdivided by category. Several links are listed more than once as we believe they are well-suited for each of the listed categories.}

Some 20 years ago, one of the best teachers author JASB has ever met, Dr. Donald Cronkite (Hope College, Holland, Michigan, USA), asked author JASB to give a presentation on internet resources for human anatomy and physiology. At that time, there were thousands of hits on those key words. Today, there are millions. Obviously, the compilation of web resources in different areas of biology that follows is not comprehensive. Instead, it is the result of our own teaching practice as well as that of our colleagues, listed in the Acknowledgments. They have generously contributed selected resources that have worked for them as individuals.

We decided to begin this list with Ethical Thinking because goodness is important. Most links pertain to more than one area of science, hence they are listed under "Interdisciplinary", following Ethical Thinking. Some of the listed resources are not free and some others may require additional time to generate a login, a password, etc. All links were verified on April 15-16, 2015.

\section{Ethical Thinking}

Making an Ethical Decision. Markkula Center for Applied Ethics. Santa Clara University. http://www.scu.edu/ethics/practicing/decision/making.pdf . Santa Clara university has some great resources! Read about their approach at http://www.scu.edu/ethics/practicing/decision/\#sthash.z6ZSz5HU.dpbs, including an app!

\section{Interdisciplinary}

Bad Science. http://www.badscience.net/

BioScience Ed Net (BEN). Digital Library Portal for Teaching and Learning in the Biological Sciences. http://www.biosciednet.org/portal/

Bill Nye. The Science Guy. http://billnye.com/
ChemSpider
Blog.
Building
Community for
Chemists. http://www.chemspider.com/blog/a-well-done-scientific-hoax-called-water- $\underline{\text { marbles.html }}$

Citizen Science. Scientific American http://www.scientificamerican.com/citizen-science/

Creature • Cast. The Unexpected World of Biology. http://creaturecast.org/

Discovery. http://www.discovery.com/

How stuff works. http://www.howstuffworks.com/ 
Howtosmile.org. All the Best Science \& Math Activities. http://howtosmile.org/

I Can Has Science? http://icanhasscience.com/

IFL Science. http://www.iflscience.com/

Improbable Research. http://www.improbable.com/

Jefferson Lab. Science Education. http://education.jlab.org/index.html

KQED Science. http://blogs.kqed.org/science/

Linda Dong. Interaction \& Industrial Designer. http://www.lindadong.com/

LiveScience. http://www.livescience.com/

Liu, D. W. 2013. Physics and Biology collaborate to color the world. CBE Life Sciences Educcation 12(2):133-138. doi: 10.1187/cbe.13-03-0056 or http://www.lifescied.org/content/12/2/133

Make: http://makezine.com/

Makedo. Start Making Your Own Creations. http://www.mymakedo.com/shop

MathBench Biology Modules. University of Maryland. http://mathbench.umd.edu/

Moment of Science. Indiana Public Media. http://indianapublicmedia.org/amomentofscience/

Montana Science Teachers Association. http://www.ivymerriot.com/montanascience/

Montana State University. Extended University. http://eu.montana.edu/SciSat/default.htm

National Aeronautics and Space Administration (NASA). http://www.nasa.gov/audience/foreducators/index.html\#.VGDrq_nF98E and http://www.nasa.gov/

New Scientist. http://www.newscientist.com/

Otherlab. https://otherlab.com/

Nature.com. http://www.nature.com/

Neil deGrasse Tyson. http://www.haydenplanetarium.org/tyson/

Popular Science. http://www.popsci.com/ 
Pure Grass $\approx$ A dramatic interpretation of Walt Whitman's Leaves of Grass by Bruce Noll. http://www.unm.edu/ banoll/about.htm

RedOrbit Your Universe Online. http://www.redorbit.com/

Science. American Association for the Advancement of Science (AAAS). http://www.sciencemag.org/

ScienceDaily. Your sorce for the latest research news. http://www.sciencedaily.com/

Science Friday. http://www.sciencefriday.com/home/index.html

Scientific American. http://www.scientificamerican.com/

Shodor. A National Resource for Computational Science Education. http://www.shodor.org/home/

Smater Every Day. https://www.youtube.com/user/destinws2

Smithsonian.com. http://www.smithsonianmag.com/?no-ist

Southern Fried Science. http://www.southernfriedscience.com/

Space.com. http://www.space.com/

STEM to STEAM. http://stemtosteam.org/

Steve Spangler Science. http://www.stevespanglerscience.com/

Student Science. A Resource of the Society for Science and the Public. https://student.societyforscience.org/

Teaching Biology. http://bioteaching.com/

TERC. https://www.terc.edu/display/HOME/Home

The American Entomologists Poet's Guide to the Orders of Insect. eBook (Kindle)

The Cultural Cognition Project. Yale Law School. http://www.culturalcognition.net/

The Naked Scientists. http://www.thenakedscientists.com/

The World's Greatests D.I.Y. Comic Website. http://www.howtoons.com/?page_id=2

TreeHugger 10 Years of Looking Forward. http://www.treehugger.com/

Welcome to Science Forward. http://macaulay.cuny.edu/eportfolios/scienceforward/ 
WIRED. http://www.wired.com/

\section{Cellular Biology, Genetics, Development}

Drosophila Sciencecourseware.org. http://www.sciencecourseware.org/vcise/drosophila/

Ghost in Your Gene. NOVA. http://www.pbs.org/wgbh/nova/genes/ Author JASB tells all his students that after watching this video - note, several versions are freely available on the web - "you will not see genetics the same way ever again."

Learn.Genetics. Genetic Science Learning Center. http://learn.genetics.utah.edu/

Scitable. Nature Publishing Group. http://www.nature.com/scitable ; http://blogs.nature.com/

Value @ ARMITA. NME ICT initiative of MHRD. http://amrita.vlab.co.in/index.php?sub=3\&brch=273\&sim=1437\&cnt=1

\section{Ecology, Environmental Sciences, Evolution, and Biodiversity}

Charles Darwin \& Evolution

1809-2009.

http://darwin200.christs.cam.ac.uk/pages/index.php?page $\mathrm{id}=\mathrm{g} 8$

Encyclopedia of Life (EOL). http://eol.org/info/ed_resources

Free Woodworking Plans. http://free.woodworking-plans.org/

Global Warming \& Climate Change Myths. Getting Skeptical About Global Warming Skepticism. Skeptical Science. https://www.skepticalscience.com/argument.php This is an invaluable resource!

Harvest of Fear. A NOVA/Frontline Special Report. http://www.pbs.org/wgbh/harvest/

Human Origins Project. National Geographic. http://www.nationalgeographic.com/explorers/projects/human-origins/

Intelligent Design on Trial. NOVA. http://www.pbs.org/wgbh/nova/evolution/intelligentdesign-trial.html . See also this link from the National Center for Science Education, http://ncse.com/creationism/legal/intelligent-design-trial-kitzmiller-v-dover , and this other link http://ncse.com/files/pub/legal/kitzmiller/highlights/2005-1220 Kitzmiller decision.pdf

Montana Outdoor Science School. Fostering a Love of the Outdoor. http://www.outdoorscience.org/

National Center for Science Education. Defending the Teaching of Evolution and Clmate Science. http://ncse.com/

National Science Teachers Association. http://www.nsta.org/ 
Network of Conservation Educators and Practitioners (NCEP). American Museum of natural History. http://ncep.amnh.org

Perkins, A. E. H. 2014. The Tangled Bank: An Introduction to Evolution. Second Edition by Carl Zimmer. Study Guide. Roberts and Company Publishers. Greenwood Village, Colorado, USA. 290 pp. This excellent book is loaded with activities fot its book companion, Zimmer (2015 listed below).

The Evolution of Man. BBC. Unfortunately, this valuable resource is no longer being updated. http://www.bbc.co.uk/sn/prehistoric_life/human/human_evolution/

Union of Concerned Scientists. Science for a Healthy Planet and a Safer World. http://www.ucsusa.org/

What does it mean to be human? Smithsonian Instiutution, National Museum of natural History. http://humanorigins.si.edu/

Zimmer, C. 2015. The Tangled Bank: An Introduction to Evolution. Second Edition. Roberts and Company Publishers. Greenwood Village, Colorado, USA. 452 pp.

http://ncse.com/files/pub/legal/kitzmiller/highlights/2005-12-20_Kitzmiller_decision.pdf

http://www.scu.edu/ethics/practicing/decision/making.pdf which we will consider using as part of the course redesign (Santa Clara University, 2014).

\section{Educational Technology}

American Association of School Librarians (AASL). A Division of the American Library Association. Transforming Learning. http://www.ala.org/aasl/standardsguidelines/best-websites/2014

Suzanne Shaffer Teaching and Learning Resources. http://sites.psu.edu/shafferpsy/

Texas Instruments. http://education.ti.com/en/us/home 